InOedia $\quad \begin{aligned} & \text { InMedia } \\ & \text { The French Journal of Media Studies }\end{aligned}$

8.2. $\mid 2020$

What do Pictures Do? (In)visibilizing the Subaltern

\title{
Adam Ganz and Steven Price, Robert De Niro at Work. From Screenplay to Screen Performance
}

New York: Palgrave Macmillan, 2020, 246 pages

Jacques Demange

\section{CpenEdition}

\section{Journals}

Electronic version

URL: https://journals.openedition.org/inmedia/2610

DOI: $10.4000 /$ inmedia.2610

ISSN: 2259-4728

Publisher

Center for Research on the English-Speaking World (CREW)

Electronic reference

Jacques Demange, "Adam Ganz and Steven Price, Robert De Niro at Work. From Screenplay to Screen Performance", InMedia [Online], 8.2. I 2020, Online since 22 October 2021, connection on 28 October 2021. URL: http://journals.openedition.org/inmedia/2610 ; DOI: https://doi.org/10.4000/inmedia.2610

This text was automatically generated on 28 October 2021

(c) InMedia 


\section{Adam Ganz and Steven Price, Robert De Niro at Work. From Screenplay to Screen Performance}

New York: Palgrave Macmillan, 2020, 246 pages

Jacques Demange

\section{REFERENCES}

Adam Ganz and Steven Price, Robert De Niro at Work. From Screenplay to Screen

Performance, New York: Palgrave Macmillan, 2020, 246 pages

1 As the leading exponent of Method Actors, Robert De Niro is well known for his preparation to the hilt as an actor. Memories of the shootings recounted by creative collaborators are full of anecdotes about his work and his constant search to create a link between the identity of his roles and his own personality.

In 2006, De Niro gifted all of his working papers to the Harry Ransom Center at the University of Texas in Austin, including numerous scripts he had annotated during production. It is based on this documentation that Adam Ganz, professor in the Department of Media Arts at the University of London, and Steven Price, professor of modern and contemporary literature and film studies at Bango University, propose a synthesis devoted to the relationship established between the actor and screenwriting.

Far from being content with a surface analysis (mentioning the additions made by De Niro and their use or not in the films), the authors consider the screenplay as an original object of study. Going back to the particularity of this type of text and the evolution of its characteristics through the years (its layout with the space occupied by the description of dramatic situations, dialogues or impressions concerning the atmosphere of certain scenes), Ganz and Price consider scripts as a hybrid material engaging a rereading of the film from the different comments that have been affixed to 
it. In the course of preliminary chapters, we are thus told a history of this particular object, often forgotten or at least neglected by historians and critics.

If the authors note that after Goodfellas, De Niro's involvement in the scripts of his films was less important, the long passages on Taxi Driver and The Last Tycoon, but also the more circumscribed analyses devoted to The Deer Hunter, Raging Bull, The King of Comedy, New York, New York, The Untouchables or Goodfellas, allow readers to realize how important this work of writing and re-elaboration was for the actor. The chronological structure of the book, devoting most of its chapters to a particular film, efficiently tracks the evolution of the place occupied by the actor in the rewriting of his films.

De Niro's involvement with the text first allows him to affirm the importance of his function as co-narrator of the film. His desire to embody the identity of his roles in the most intense way possible is fully realized through his various annotations, which frequently exceed the length of the script itself. By dwelling on numerous details (the shifting use of the "I" or "he" in the commentary produced by the actor which illustrates the fusional tendency of his acting style) or certain more general aspects (the creation of a biography for the character), Ganz and Price prove that the text, its reading and writing, is an essential component in De Niro's approach to acting. It allows him to get more familiar with his roles, to explore the identity of his characters and learn about them through a creative writing process.

6 Rather than treating these observations as anecdotal or factual, the two authors use them to propose an analysis of the actor's skills. The chronological structure of their work naturally invited this approach. Going back to De Niro's first films and his training in television, the book articulates some of the actor's stylistic specificities to his methodological originality (for instance, his relationship to stage acting or performance). Using numerous bibliographical references (reflected in the generous bibliography section of the book), the authors recall the nature of the dialogue maintained by the actor with his acting partners. For instance, when it comes to his relationship with the young Jodie Foster on the set of Taxi Driver, De Niro's work methodology directly influenced the relationships established between their characters and the impact of their relationship on the screen. One also thinks of the chapter devoted to the actor's taste for improvisations. Here again, this acting technique is not limited to the moment of shooting, but is prepared and activated in his work on the script. De Niro rewrites certain dialogues from words and formulas found during rehearsals, and does not hesitate to modify the lines of the other actors in the film as well.

$7 \quad$ It is here that the modalities of the passage between the screenplay and the screen performance, the preparatory work and its outcome on the screen, are defined. This orientation also determines the writing of the two authors, which is constantly divided between literary and filmic analysis. Their work ultimately proves the possibility of an encounter between these two disciplines that would go beyond the sole issues of adaptation to reveal the multiplicity of approaches induced by the cinematographic object. The main subject and producer of this passage remains the actor who occupies a central place between the text and the screen. In this perspective, the transdisciplinary perspective of the book provides a fresh insight within the field of actoral studies, as the specificities of play are analyzed through the prism of the text and the actor's reappropriation of it. I would be curious to see Ganz and Price's methodology extended to other examples that would prove that the excellence of their approach is not only 
due to the exemplarity of a unique case but enables film studies to open new theoretical and practical horizons.

\section{AUTHORS}

\section{JACQUES DEMANGE}

Université de Strasbourg 